\title{
An Exploratory Analysis Of The Relationship Between Consumer Socialization Agents And Children's Consumption Of Tobacco
}

Phylis Mansfield, (E-mail: pmm16@psu.edu), Penn State, Behrend Charisse Nixon, (E-mail: cln5@psu.edu), Penn State, Behrend Peg Thoms, (E-mail: mat6@psu.edu), Penn State, Behrend

\begin{abstract}
This paper expands the use of marketing-related research for the study of tobacco consumption by children, to include consumer socialization theory. The relationships between three socialization factors, parental modeling, parental style of interaction, and parental communication, and a child's intent to consume tobacco were explored. In a sample of $5^{\text {th }}$ and $8^{\text {th }}$ grade students, significant relationships were found between the child's intent to smoke and both parental modeling and parental style of interaction.
\end{abstract}

\section{INTRODUCTION}

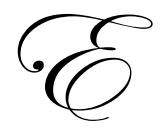

very day in America approximately 4,000 adolescents begin smoking tobacco (CDC 2003), and at least one-third of them are expected to die from a tobacco-related disease (Peracchio and Luna 1998). It is estimated that close to 35\% of high school students are smokers (Pechmann and Shih 1999; CDC 2000). The majority of smokers cite that they began smoking either in their childhood or in their teens, with the average age of initiation at 12.3 years (Peracchio and Luna 1998; Harell, Bangdiwala, Dent, Webb, and Bradely 1998). Smoking cigarettes has been referred to as a national epidemic in childhood disease, since the only age group to begin smoking in large numbers continues to be children and adolescents (Peracchio and Luna 1998).

Legislators began to see the societal issues of tobacco use in the late 1960s, and by January, 1971 completely banned the advertisement of cigarettes on television (Lamdin 1999). Almost three decades later, the 1998 Master Settlement Agreement, between the government and tobacco companies, required the elimination of outdoor advertising, brand licensing on non-tobacco merchandise, and cartoon characters in any form associated with tobacco (Krugman and King 2000). The Master Settlement of 1998 occurred due to the negative health impact of tobacco, reported to kill 440,000 Americans annually and responsible for $\$ 157$ billion in annual health-related costs (Givel and Glantz 2004).

Even though the tobacco industry no longer promotes their products directly, the occurrence of smoking by actors in both television and movies has actually increased during the last decade. The "frequency of smoking in the top-grossing movies in the USA has about doubled since 1990, when the US tobacco industry first promised Congress that it would stop paid product-placement in movies" (Meyerson 2003, p. 258). Since 2000, tobacco companies have been using a new technique in direct marketing called "buzz marketing". This technique sends actors and models into bars and clubs to conspicuously consume certain brands of tobacco in hopes of having another patron "bum" a cigarette from them (Spethmann 2004). Even though these product placement and buzz marketing tactics are directed to adults rather than children, they are evidence of the ubiquitous form of advertising cigarette companies continue to use. 
With regard to tobacco use among children and adolescents, recent movements among educators, public service marketers, and legislators have focused on ways to educate young people on the harmful effects of tobacco use and encourage the policy of abstinence (Azar 1999; CDC 2003; Fichtenberg and Glantz 2002; Landman, Ling, and Glantz 2002; Spethmann 2004; Tannenbaum 1998).

Researchers in the areas of psychology and sociology have investigated the antecedents to smoking behavior, identifying relationships between smoking and personality variables, parental habits, parental style, or peer pressure. Research in the marketing discipline has focused primarily on mass media, primarily the effect of advertising campaigns, their message content, and product placements in movies (Cohen 2000; Krugman and King 2000; Pollay and Lavack 1993; Pechman and Knight 2002). This study expands the use of marketing-related research techniques for the study of tobacco consumption by young people to include the theory of consumer socialization.

\section{CONSUMER SOCIALIZATION}

In consumer research, the concept of consumer socialization was first used by Ward (1974) to describe the process of forming purchasing and consumption attitudes, habits, and knowledge. Based on social learning theory, consumer socialization research suggests that consumer behaviors are learned during early childhood and pre-adult years through the influence of socialization agents such as parents, media sources, peers, and educational institutions (Churchill and Moschis 1979; Moschis and Moore 1984).

Consumer socialization, first addressed in the 1970's, was defined as a lifelong process through which individuals acquire skills, knowledge, habits, attitudes, and values that affect their "present" and "eventual" behavior as consumers in the marketplace (Baumrind, 1978; Ward, 1974; Ward, Wackman, and Wartrella 1977). Based on the social learning model in which children learn to be consumers as they interact with socialization agents (Moschis and Moore 1984), the primary influencers are parents, peers, schools, and mass media (Bush, Smith, and Martin 1999). Research identifies the most significant influence on children's consumer behavior as their parents (Caruana and Vassallo 2003; Mascarenhas and Higby 1993). Three of the methods used by parents to influence their children's consumer behavior include 1) modeling, 2) parental styles of interaction, and 3) providing them with information about consumption-related activities (Grossbart, Carlson, and Walsh 1991).

Parental modeling occurs when children emulate the behaviors, both positive and negative, of their parents. The parental style of interaction refers to the degree of leniency or authoritative control a parent exhibits over the child's behavior (Moschis 1985; Ward 1974). The level of communication within the family also has an impact on consumer socialization when parents provide their children with information about consumption-related activities (Grossbart, Carlson, andWalsh 1991; Moschis 1985). This study explores the relationship each of these methods has with a child's consumer behavior in the form of his or her self-reported intent to consume cigarettes (See Figure 1).

\section{METHODOLOGY}

Questionnaires were distributed to a nonrandom, purposive sample of elementary and middle school students enrolled in four public schools in a Northeastern county. The four schools were selected with attention to representation of different socioeconomic backgrounds. Respondents were recruited under the research university's Human Subjects Review Board requirements, with parental consent obtained through the county's school board and governing policies. A self-reported survey instrument was distributed in the schools' fifth and eighth-grade health classes by the health teacher. The study researchers were not present. Students were informed by the teacher that the survey was about consumer and smoking-related issues and were read a statement about anonymity, the fact that there were no right or wrong answers, and that they could stop answering the survey at any time. A total of 791 surveys were received from the schools, which represented close to $90 \%$ of the students in those grades. Due to incomplete data, the final sample was 602 .

A profile of the sample is provided in Table 1. The majority of the respondents were Caucasian $(96.2 \%)$ and male $(50.6 \%)$ which is reflective of the demographic characteristics in the Northeastern County where the study occurred. The number of households reporting to a recent survey in the county were reported to be Caucasian (91.5\%, Black (6.5), Hispanic (2.2), and Asian (.5) (U.S. Census Bureau 2003). There were 356 students in the fifth grade, 
representing $59 \%$ of the sample, and 247 were in the eighth grade. The percentage of students who were between 9 and 11 years of age was $58.7 \%$ and those who were 12 to 15 years of age made up $41.3 \%$; these percentages reflect the numbers in the fifth and eighth-grade categories. When asked about the smoking habits of friends and family, $33.3 \%$ of the total sample reported they had friends who smoked, $41.7 \%$ reported their mother smoked, and $36.3 \%$ reported their father smoked. These percentages differ between the fifth and eighth-grade levels, reported in Table 1. Recent studies about the smoking behaviors of the adults in the sampled county were reported to be from $30 \%$ of 30 to 54-year olds, to $45 \%$ of 18 to 29 -year olds (BRFSS 2004). Therefore, our numbers of parents who smoke as reported by the children appear to be within appropriate ranges.

Table 1: Sample Characteristics

N=602
\begin{tabular}{|l|c|c|}
\hline & Number & Percentage of Sample \\
\hline Male & 305 & 50.5 \\
\hline Female & 29 & 49.6 \\
\hline $5^{\text {th }}$ Grade & 355 & 59 \\
\hline $8^{\text {th }}$ Grade & 247 & 41 \\
\hline Age: & & 58.7 \\
\hline 9 to 11 years & 353 & 41.3 \\
\hline 12 to 15 years & 248 & 96.2 \\
\hline Race: & & 1.0 \\
\hline White & 577 & .9 \\
\hline Black & 6 & .3 \\
\hline Hispanic & 5 & .7 \\
\hline Asian & 2 & 1.1 \\
\hline Native American & 4 & \\
\hline Other & 7 & 41.7 \\
\hline Smoking Habits: & & 36.3 \\
\hline Total Sample- & & 33.3 \\
\hline Mother Smokes & 251 & \\
\hline Father Smokes & 218 & \\
\hline Friend Smokes & 201 & \\
\hline
\end{tabular}

\section{MEASUREMENT OF VARIABLES}

Since the issue of concern was the child's intent to consume cigarettes as a product rather than brand preferences of cigarettes, the construct of "modeling" parental behavior was measured by two items, 1) does your mother smoke?, and 2) does your father smoke? With regard to parental styles of interaction, one example of interaction between children and parents in the marketplace is the level of autonomy offered to the child in the choice of products or brands. Carlson and Grossbart (1988) referred to this concept as choice independence and developed a scale to measure the degree to which a child can exercise autonomy in the purchase of products that the child will consume. The scale is based on responses of $1=$ "I choose by myself," $2=$ ="I choose, but talk to my parents first," $3=$ "my parents choose but talk to me first," and 5="my parents chooses for me." Higher scores indicate less autonomy, whereas lower scores imply the child is allowed a high degree of freedom in the purchase of products they consume.

The third factor of influence, providing children with information, was measured using a scale developed by Moschis and Moore (1984) that addressed the degree of family communication about purchasing activities. The multiple-item scale addresses issues such as "My parents and I talk about things we see or hear advertised," "I ask my parents for advice about buying things," and "My parents and I don't agree on what things I should or shouldn't buy." Based on responses of $1=$ "very often", to $5=$ "never", lower scores suggest that children and adolescents discuss purchase-related activities and things they have seen in advertising often with their parents. Higher scores suggest they do so rarely. 
The reliability of multiple-item constructs was assessed, with a reported Cronbach's alpha for "Choice Independence" of .74 and for "Purchase-Related Communication" of .42. In the original study by Moschis and Moore (1984) the Cronbach's alpha was reported to be .42 as well.

ANALYSIS AND RESULTS

Given that this study was of an exploratory nature rather than a causal one, we addressed the relationships between the consumer socialization variables and a child's intent to consume tobacco (smoking) with bivariate correlation analysis. The correlations are reported in Table 2. The results support a significant ( $<$.05) relationship between the child's intent to smoke and modeling smoking behavior for both parents. There was also a significant, but negative, relationship between the child's intent to smoke and choice independence. Since higher scores for choice independence reflect less autonomy, the negative relationship in this case would signify that the more independence the child has with regard to making choices about other consumable products, the greater is his or her intent to smoke. Finally, no significant relationship was found between the child's intent to smoke and purchaserelated communication.

Table 2: Simple Correlations*

\begin{tabular}{|c|c|c|c|c|}
\hline & IS & CI & $\mathbf{D C}$ & DS \\
\hline CI & $(.13)^{* * *}$ & & & \\
\hline PC & .09 & $(.26)$ & & \\
\hline PS & $.21 * *$ & $(.08)$ & .01 & \\
\hline Mean & 1.45 & 1.98 & 2.80 & .78 \\
\hline S.D. & .92 & .62 & .83 & .80 \\
\hline
\end{tabular}

*IS is Intent to Smoke, CI is Choice Independence, PC is Purchase-related Communication, and PS is Parent Smokes.

$* *$ Significant at $\mathrm{p}<.05$

\section{DISCUSSION}

The results of this study suggest that children in the fifth and eighth-grade model their parents' consumption of tobacco. Additionally, it appears that the greater the independence a child has in his or her choice of purchases of consumer products at the age of 9 to 12 years, the more likely he or she is to state an intention to smoke. Perhaps the socialization style of allowing the child greater freedom in making decisions about consumer issues may reflect greater freedom in other decisions, such as the use of tobacco, however, additional research would certainly be required to substantiate this assumption. This finding supports previous studies which found that when parents have a more authoritative parenting style, their children are less likely to be smokers (Adamczyk-Robinette, Fletcher, and Wright 2002; Cohen and Rice 1997). Lastly, the interaction between child and parent about advertising or purchaserelated consumption of products did not appear to have a spillover effect with the product of tobacco and the child's intent to smoke. This information was surprising, given that the amount of communication and interaction in general between parent and child would suggest that they would discuss topics in addition to consumer-related ones. This is also an interesting finding since there are numerous anti-tobacco marketing campaigns that focus on the relationship of talking with one's child about tobacco consumption in order to reduce his or her likelihood to smoke. This study would suggest that additional research is needed to substantiate that relationship and to determine the effectiveness of the resources spent in that manner. 
Figure 1: Model Of Parental Consumer

Socialization Factors And Child's Intent To Consume Cigarettes

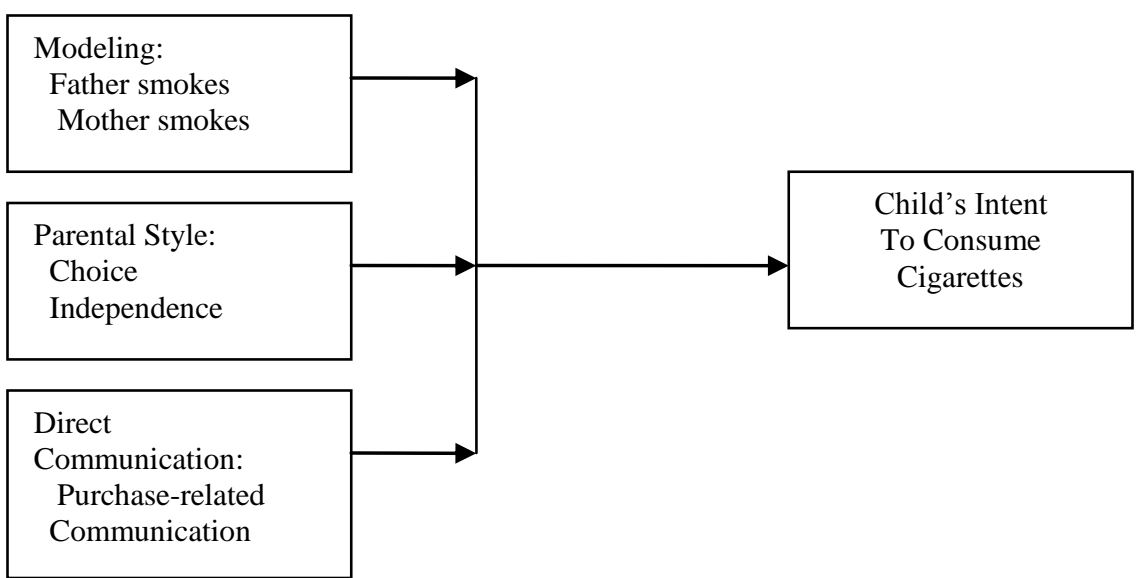

\section{REFERENCES}

1. Adamczyk-Robinette, Stacey L., Anne C. Fletcher, and Kristie Wright (2002), Understanding the Authoritative Parenting-Early Adolescent Tobacco Use Link: The Mediating Role of Peer Tobacco Use, Journal of Youth and Adolescence, 31(4), August, 311-318.

2. $\quad$ Azar, Beth (1999), Antismoking Ads That Curb Teen Smoking, The Monitor, 30 (1), 1-2.

3. Baumrind, Diane (1978), Parental Disciplinary Patterns and Social Competence in Children, Youth and Society, 9(March), 239-276.

4. $\quad$ BFRSS, Behavioral Risk Factor Survey (2004), reported by the Program Director of the Erie County Department of Health, May 17, 2005.

5. Bush, Alan, Smith, Rachel, and Martin, Craig (1999), The Influence of Consumer Socialization Variables on Attitude Toward Advertising: A Comparison of African-Americans and Caucasians, Journal of Advertising Research, 28(3), 13-24.

6. Carlson, Les and Grossbart, Sanford (1988), Parental Style and Consumer Socialization of Children, Journal of Consumer Research, 15(June), 77-94.

7. Caruana, A. and Vassallo, R. (2003), Children's Perception of Their Influence Over Purchases: The Role of Parental Communication Patterns, The Journal of Consumer Marketing, 20(1), 55-76.

8. Centers for Disease Control and Prevention (2000), Trends in Cigarette Smoking in High School Students United States 1991-1999, Morbidity and Mortality Weekly Report, 49, 755-758.

9. Centers for Disease Control and Prevention (2003), Youth and Tobacco Use: Current Estimates, National Center for Chronic Disease Prevention and Health Promotion, December, available at www.cdc.gov/tobacco/research_data/youth/Youth_Factsheet.htm. Date of access: June 6, 2005.

10. Churchill, Gilbert and Moschis, George P. (1979), Television and Itnerpersonal Influences on Adolescent Consumer Learning, Journal of Consumer Research, 6(1), 23-35.

11. Cohen, D. A. and J. Rice (1997), Parenting Styles, Adolescent Substance Use, and Academic Achievement, Journal of Drug Education, 27, 199-211.

12. Cohen, Joel (2000), Playing to Win: Marketing and Public Policy at Odds Over 'Joe Camel', Journal of Public Policy and Marketing, 19(2), 155-167.

13. Fichtenberg, Caroline and Glantz, Stanton (2002), Youth Access Interventions Do Not Affect Youth Smoking, Pediatrics, 109(6), 1088-1092.

14. Givel, Michael, and Glantz, Stanton (2004), The 'Global Settlement' with the Tobacco Industry: 6 Years Later, American Journal of Public Health, February, 94 (2), p. 218-224. 
15. Grossbart, Sanford, Carlson, Les and Walsh, A. (1991), Consumer Socialization and Frequency of Shopping With Children, Academy of Marketing Science, 19(3), 155-163.

16. Harrell, J. S., S. Bangdiwala, S. Dent, J. Webb, and C. Bradely (1998), Smoking Initiation in Youth: The Roles of Gender, Race, Socioeconomics, and Developmental Status, Journal of Adolescent Health, 23, 271279.

17. Krugman, Dean and King, Karen (2000), Teenage Exposure to Cigarette Advertising in Popular Consumer Magazines, Journal of Public Policy and Marketing, 19 (Fall), 183-188.

18. Lamdin, Douglas J. (1999), Event Studies of Regulation and New Results on the Effect of the Cigarette Advertising Ban, Journal of Regulatory Economics, 16(2), 187-197.

19. Landman, Anne, Ling, Pamela, and Glantz, Stanton (2002), Tobacco Industry Youth Smoking Prevention Programs: Protecting the Industry and Hurting Tobacco Control, American Journal of Public Health, 92(6), 917-930.

20. Mascarenhas, O. and Higby, M. (1993), Peer, Parent, and Media Influences in Teen Apparel Shopping, Academy of Marketing Science, 21(1), 53-58.

21. Meyerson, Matthew (2003), Smoking in Movies: A Major Problem and a Real Solution, The Lancet, 362 (July), p 258-259.

22. Moschis, George (1985), The Role of Family Communication in Consumer Socialization of Children and Adolescents, Journal of Consumer Research, 11(4), 898-914.

23. Moschis, George P. and Moore, Roy (1984), Anticipatory Consumer Socializaiton, Academy of Marketing Science, 12(4) 109-123.

24. Peracchio, Laura and Luna, David (1998), The Development of an Advertising Campaign to Discourage Smoking Initiation among Children and Youth, Journal of Advertising, 27(3), 49-56.

25. Pechmann, Cornelia and Knight, Susan (2002), An Experimental Investigation of the Joint Effects of Advertising and Peers on Adolescents' Beliefs and Intentions About Cigarette Consumption, Journal of Consumer Research, 29(1), 5-20.

26. __ and Shih, Chuan-Fong (1999), Smoking Scenes in Movies and Anti-smoking Advertisements Before Movies: Effects on Youth, Journal of Marketing, 633), 1-14.

27. Pollay, Richard and Lavack, Anne (1993), The Targeting of Youths by Cigarette Marketers: Archival Evidence on Trial, Advances in Consumer Research, 20, 266-271.

28. Spethman, Betsy (2004), Tobacco's Two Tiers, Promo Magazine, January, available at www.promomagazine.com/law/marketing_tobaccos_two_tiers/. Date of access: September 15, 2004.

29. Tannenbaum, David (1998), Smoking Guns I: Marketing to Kids, Multinational Monitor, July/August, 19 (7/8), 22-23.

30. Ward, Scott (1974), Consumer Socialization, Journal of Consumer Research, 1(2), 1-14.

31. Ward, Scott, Wackman, Daniel, and Wartella, Ellen (1977). How Children Learn to Buy. Beverly Hills, CA: Sage Publications, Inc. 